\title{
FAKTOR-FAKTOR YANG MEMPENGARUHI TINGKAT PENGETAHUAN IBU RUMAH TANGGA TENTANG KONSEP DAGING SAPI YANG ASUH DI DESA BATURETNO KECAMATAN BATURETNO KABUPATEN WONOGIRI
}

\author{
(Factors Influencing Women's Knowledge toward the Concept of "ASUH"in Meat \\ Consumption, A Survey on Housewives in Baturetno Village of Baturetno Subdistrict of \\ Wonogiri Regency) \\ E. Setyaningsih, S. Gayatri dan B.T. Eddy \\ Program Studi S1 Agribisnis Fakultas Peternakan dan Pertanian \\ Universitas Diponegoro, Kampus Tembalang - Semarang 50275 \\ Email: eviisetya20.es@gmail.com
}

Diterima 25 Agustus 2017, disetujui 31 Oktober 2017

\begin{abstract}
ABSTRAK
Tujuan penelitian ini adalah 1) mengetahui tingkat pengetahuan ibu rumah tangga tentang daging sapi yang ASUH. 2) menganalisis faktor-faktor yang mempengaruhi tingkat pengetahuan ibu rumah tangga terhadap konsep daging sapi yang ASUH. Penelitian ini dilaksanakan pada Februari 2017 sampai Maret 2017 di Desa Baturetno Kecamatan Baturetno Kabupaten Wonogiri. Metode penelitian ini adalah survai. Metode penentuan sampel menggunakan multistage random sampling dengan jumlah responden 97 orang ibu rumah tangga. Analisis data secara deskriptif dan regresi linier berganda. Hasil penelitian menunjukkan bahwa tingkat pengetahuan ibu rumah tangga termasuk dalam kriteria sedang. Hasil analisis menunjukkan secara signifikan faktor-faktor yang mempengaruhi tingkat pengetahuan ibu rumah tangga tentang konsep daging sapi yang ASUH adalah pendidikan, jumlah anggota keluarga, pendapatan keluarga, kesempatan memperoleh informasi dan keanggotaan dalam organisasi masyarakat, sedangkan variabel usia tidak berpengaruh secara signifikan.
\end{abstract}

Kata Kunci: pengetahuan, ibu rumah tangga, daging sapi, ASUH

\section{ABSTRACT}

The purposes of this study were to: 1) Know the women's knowledge on the concept of "ASUH" in meat consumption. 2) Analyze factors influencing women's knowledge on the concept of "ASUH" in meat consumption. The study was conducted from February 2017 to March 2017 in the Baturetno Village of Baturetno District of Wonogiri Regency. Survey method was used in this research. Multistage random sampling was employed among 97 housewives in Baturetno Village. In addition, multiple linier regression was used for data analysis. The result showed that the level of woman's knowledge were in the medium criteria. The result of multiple regression analysis showed that there were significant influence between education level, family size, family income, opportunity to get information, membership in organization toward woman' knowledge, however there was no significant influence between age and woman 'knowledge.

Keywords: knowledge, housewife, "ASUH" meat, consumption

\section{PENDAHULUAN}

Daging sapi merupakan salah satu sumber pangan hewani dari komoditas peternakan. Unsur gizi yang cukup tinggi berupa protein dan energi serta harganya yang lumayan terjangkau membuat daging sapi digemari masyarakat. Daging sapi sebagai salah satu sumber pangan hewani diharapkan 
memiliki mutu dan kualitas yang bagus, akan tetapi kesadaran masyarakat mengenai pemilihan daging sapi yang baik masih tergolong rendah sehingga banyak terjadi kasus pelanggaran dalam penjualan daging sapi.

Salah satu kasus kecurangan dalam perdagangan daging sapi yaitu ditemukannya daging sapi oplosan di Kecamatan Baturetno, Kabupaten Wonogiri pada bulan September 2014 (Republika, 2014). Martindah dan Saptati (2007) menyatakan bahwa konsumen cenderung lemah dalam memperhatikan kualitas sehingga mendorong pelaku usaha yang tidak bertanggung jawab untuk meraih keuntungan besar tanpa memikirkan kerugian yang diderita konsumen.

Kasus kecurangan dalam perdagangan daging sapi tersebut dapat dicegah dengan cara meningkatkan kesadaran masyarakat mengenai cara pemilihan daging sapi yang baik, khususnya ibu rumah tangga yang berperan sebagai penanggung jawab konsumsi pangan keluarga. Hal ini sesuai dengan pendapat Setiabudi et al. (2013) yang menyatakan bahwa perempuan pada umumnya lebih banyak berperan sebagai pengambil keputusan dalam kegiatan pembelian kebutuhan rumah tangga.

Daging yang baik dan sehat untuk dikonsumsi yaitu daging yang aman dan halal dengan tanda-tanda: bersih/terang, lapisan luar kering, berasal dari rumah potong (RPH /RPA) dengan sistem pemotongan yang halal, sudah ditiriskan, aroma tidak amis dan tidak bau asam, daging masih elastik dan tidak kaku, tidak ada memar (Suryana, 2007). Kata ASUH mengandung empat pengertian yaitu : 1) Aman yaitu tidak mengandung bibit penyakit, racun (toksin), residu obat dan hormon, cemaran logam berat, cemaran pestisida, cemaran zat berbahaya serta bahanbahan/unsur-unsur lain yang dapat menyebabkan penyakit dan akan mengganggu kesehatan manusia. 2) Sehat yaitu daging memiliki zat-zat yang dibutuhkan serta berguna bagi kesehatan dan pertumbuhan manusia. 3) Utuh yaitu daging tidak tercampur dengan bagian lain dari hewan tersebut atau bagian dari hewan lain yang tidak layak konsumsi. 4) Halal yaitu daging sapi merupakan hasil produksi ternak sapi yang tidak diharamkan dan penyembelihannya dilakukan sesuai dengan syariat agama Islam (Direktorat Kesmavet, 2003). Pengujian daging yang sehat secara fisik dapat juga dilakukan sendiri oleh masyarakat (konsumen) yaitu dengan melihat beberapa kriteria yaitu warna daging merah cerah, aroma daging agak amis sampai tidak berbau, lapisan lemak daging tipis kecuali bagian tertentu, serabut otot/daging agak kasar, daging kenyal. Penanganan hewan dan daging yang kurang baik dan tidak higienis akan erpengaruh pada kehalalalan, mutu dan keamanan daging yang dihasilkan. Aspek yang perlu diperhatikan terdiri dari hygiene, sanitasi, kehalalan dan kesejahteraan hewan (Zulfanita et al., 2012).

Tujuan dari penelitian ini adalah 1) Mengetahui tingkat pengetahuan daging sapi yang aman, sehat, utuh dan halal (ASUH) pada ibu rumah tangga. 2) Menganalisis pengaruh faktor-faktor karakteristik internal dan eksternal yang meliputi usia, pendidikan, jumlah anggota keluarga, pendapatan keluarga, kesempatan memperoleh informasi dan keanggotaan dalam organisasi masyarakat terhadap pengetahuan ibu rumah tangga tentang konsep daging sapi yang ASUH di Desa Baturetno, Kecamatan Baturetno, Kabupaten Wonogiri.

\section{METODE PENELITIAN}

Penelitian dilaksanakan pada bulan Februari 2017 sampai dengan Maret 2017 di 
Desa Baturetno, Kecamatan Baturetno, Kabupaten Wonogiri. Lokasi dipilih dengan pertimbangan bahwa desa tersebut merupakan satu-satunya desa yang memiliki pasar daging di Kecamatan Baturetno (Badan Pusat Statistik Kabupaten Wonogiri, 2015).

Penelitian ini menggunakan metode survei. Survei adalah suatu metode penelitian yang merujuk pada sejumlah individu pada daerah tertentu mengenai suatu permasalahan dengan tujuan untuk mendapatkan informasi yang mewakili kondisi suatu daerah (Wirartha, 2006).

Penentuan sampel menggunakan multistage random sampling (Ilustrasi 1). Kriteria responden yang diambil adalah ibu rumah tangga murni ataupun ibu rumah tangga yang bekerja, berstatus menikah ataupun janda. Penentuan jumlah responden menggunakan rumus Slovin dengan presisi $10 \%$ sehingga didapatkan jumlah responden sebanyak 97 orang ibu rumah tangga. Penentuan jumlah responden menggunakan rumus Slovin sebagai berikut (Hamdi, 2014):

$$
\begin{aligned}
& \mathrm{n}=\frac{\mathrm{N}}{1+\mathrm{N}(\mathrm{e})^{2}} \\
& \mathrm{n}=\frac{2.979}{1+2.979(0,1)^{2}} \\
& \mathrm{n}=\frac{2.979}{(30,79)^{2}}=96,7
\end{aligned}
$$

(dibulatkan menjadi 97 responden)
Keterangan: $\mathrm{n}$ = Jumlah sampel
$\mathrm{N}=$ Jumlah populasi
e $=$ batas toleransi kesalahan $(10 \%)$

Rincian jumlah responden pada masingmasing dusun terpilih di Desa Baturetno terdapat pada Ilustrasi 1 dan Tabel 1.

Pengumpulan data pada penelitian ini menggunakan kuesioner yang diisi dengan wawancara untuk mendapatkan informasi yang berkaitan dengan penelitian. Data sekunder pendukung diperoleh dari kantor Desa Baturetno, kantor Kecamatan Baturetno,

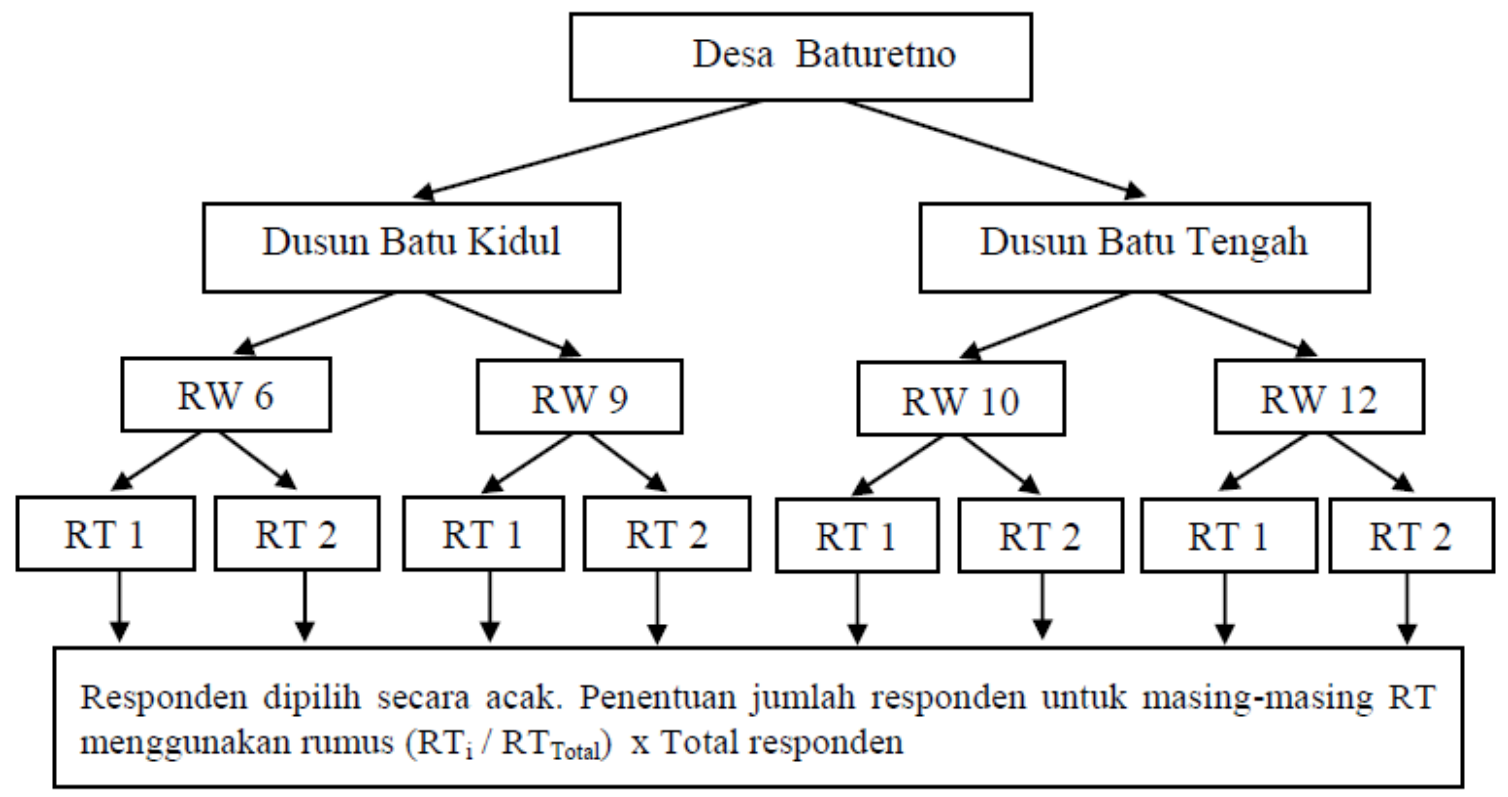

Ilustrasi 1. Kerangka Sampling 
Tabel 1. Jumlah Responden Penelitian di Desa Baturetno

\begin{tabular}{|c|c|c|c|}
\hline No. & Lokasi & Jumlah Kepala Keluarga & $\begin{array}{l}\text { Jumlah responden } \\
\left(\mathrm{RT}_{\mathrm{i}} / \mathrm{RT}_{\text {Total }}\right) \times 97\end{array}$ \\
\hline & & --- (orang) --- & --- (orang) --- \\
\hline & Dusun Batu Kidul & & \\
\hline & RW 6 RT 1 & 71 & 17 \\
\hline & RW 6 RT 2 & 53 & 13 \\
\hline & RW 9 RT 1 & 35 & 8 \\
\hline & RW 9 RT 2 & 60 & 14 \\
\hline \multicolumn{4}{|c|}{ Dusun Batu Tengah } \\
\hline & RW 10 RT 1 & 60 & 14 \\
\hline & RW 10 RT 2 & 43 & 10 \\
\hline & RW 12 RT 1 & 58 & 14 \\
\hline & RW 12 RT 2 & 28 & 7 \\
\hline & Jumlah & 403 & 97 \\
\hline \multicolumn{4}{|c|}{ Sumber: Data Primer Diolah (2017). } \\
\hline \multicolumn{4}{|c|}{ Tabel 2. Operasionalisasi Variabel } \\
\hline & Variabel & Indikator & $\begin{array}{c}\text { Skala } \\
\text { pengukuran }\end{array}$ \\
\hline \multirow{2}{*}{\multicolumn{2}{|c|}{$\begin{array}{l}\mathrm{X}_{1} \\
\text { Usia (tahun) }\end{array}$}} & $\leq 30$ & Ordinal \\
\hline \multirow{4}{*}{\multicolumn{2}{|c|}{ Usia (tahun) }} & $31-40$ & \\
\hline & & $41-50$ & \\
\hline & & $51-60$ & \\
\hline & & $>60$ & \\
\hline \multicolumn{2}{|c|}{$\mathrm{X}_{2}$} & Tidak lulus SD & Ordinal \\
\hline \multirow{4}{*}{\multicolumn{2}{|c|}{ Pendidikan }} & Lulus SD & \\
\hline & & Lulus SMP & \\
\hline & & Lulus SMA & \\
\hline & & Lulus PT/Akademi & \\
\hline $\mathrm{X}_{3}$ & & 1 & Ordinal \\
\hline \multirow{4}{*}{\multicolumn{2}{|c|}{ Jumlah anggota keluarga (orang) }} & 2 & \\
\hline & & 3 & \\
\hline & & 4 & \\
\hline & & $>4$ & \\
\hline $\mathrm{X}_{4}$ & & $\leq 1.000 .000$ & Ordinal \\
\hline \multirow{4}{*}{\multicolumn{2}{|c|}{ Pendapatan keluarga (Rp/bulan) }} & $1.100 .000-1.500 .000$ & \\
\hline & & $1.600 .000-2.000 .000$ & \\
\hline & & $2.100 .000-2.500 .000$ & \\
\hline & & $>2.500 .000$ & \\
\hline \multirow{5}{*}{\multicolumn{2}{|c|}{$\begin{array}{l}X_{5} \\
\text { Kesempatan memperoleh informasi (satu } \\
\text { bulan terakhir) }\end{array}$}} & 0 kali & Ordinal \\
\hline & & 1 kali & \\
\hline & & 2 kali & \\
\hline & & 3 kali & \\
\hline & & $>3$ kali & \\
\hline \multirow{5}{*}{\multicolumn{2}{|c|}{$\begin{array}{l}\mathrm{X}_{6} \\
\text { Keanggotaan dalam organisasi } \\
\text { masyarakat (satu bulan terakhir) }\end{array}$}} & 0 & Ordinal \\
\hline & & 1 & \\
\hline & & 2 & \\
\hline & & 3 & \\
\hline & & $>3$ & \\
\hline
\end{tabular}

Sumber: Data Primer Diolah (2017). 
Badan Pusat Statistik Kabupaten Wonogiri serta referensi-referensi lain berupa artikel, jurnal, buku, internet, dan media publikasi lain.

Instrumen yang digunakan dalam penelitian ini adalah kuesioner. Pengukuran instrumen penelitian dilakukan dengan metode skoring. Terdapat 20 pertanyaan yang diajukan kepada responden. Pengukuran nilai pada setiap pertanyaan menggunakan skor angka 1 sampai dengan 5 sehingga diperoleh rentang nilai antara 20 sampai 100 . Rentang nilai tersebut kemudian dibagi menjadi 3 kategori. Kategori pengetahuan tinggi dengan skor 74 - 100; kategori pengetahuan sedang dengan skor 47 - 73; kategori pengetahuan rendah dengan skor $20-46$. Operasionalisasi variabel penelitian tercantum pada Tabel 2 .

Analisis data dalam penelitian ini menggunakan regresi linier berganda. Data yang akan dianalisis harus memenuhi syarat kenormalan data dan uji asumsi klasik.

Pengujian hipotesis dalam penelitian ini menggunakan uji $F$ (serempak) dan uji $t$ (parsial) serta dilengkapi dengan analisis koefisien determinasi. Persamaan regresi linier berganda mengacu pada Sulaiman (2004) sebagai berikut:

$\mathrm{Y}=\mathrm{a}+\mathrm{b}_{1} \mathrm{X}_{1}+\mathrm{b}_{2} \mathrm{X}_{2}+\mathrm{b}_{3} \mathrm{X}_{3}+\mathrm{b}_{4} \mathrm{X}_{4}+\mathrm{b}_{5} \mathrm{X}_{5}+$ $\mathrm{b}_{6} \mathrm{X}_{6}+\mathrm{e}$

Keterangan:

$\mathrm{Y}=$ Tingkat pengetahuan ibu rumah tangga (skor)

$\mathrm{X}_{1}=$ Usia (skor)

$\mathrm{X}_{2}=$ Pendidikan (skor)

$\mathrm{X}_{3}=$ Jumlah anggota keluarga (skor)

$\mathrm{X}_{4}=$ Pendapatan keluarga keluarga (skor)

$\mathrm{X}_{5}=$ Kesempatan memperoleh informasi (skor)

$\mathrm{X}_{6}=$ Keanggotaan dalam organisasi (skor)

$\mathrm{a} \quad=$ konstanta (intersept)

$\mathrm{b} \quad=$ koefisien regresi pada masing-masing variabel bebas.

e $=$ error

\section{HASIL DAN PEMBAHASAN}

\section{Karakteristik Responden}

Berdasarkan penelitian, diperoleh hasil mengenai karakteristik ibu rumah tangga seperti yang tertera pada Tabel 3. Data pada Tabel 3 menunjukkan bahwa responden yang terpilih paling banyak berusia $41-50$ tahun $(32,99 \%)$ dan sebagian besar responden berlatar belakang pendidikan lulus SMA $(57,73 \%)$.

Sebanyak 36,08\% responden memiliki jumlah anggota keluarga sebanyak 3 orang. Pendapatan responden berkisar kurang dari Rp $1.600 .000-2.000 .000$ per bulan (36,08\%). Kesempatan responden dalam memperoleh informasi mengenai konsep daging sapi yang ASUH sebanyak 2 kali $(46,39 \%)$ dan sebanyak $47,42 \%$ responden hanya mengikuti 2 organisasi.

Berdasarkan hasil penelitian di lapangan diperoleh informasi bahwa sebanyak 54,64\% ibu rumah tangga di Dusun Batu Kidul dan Dusun Batu Tengah adalah ibu rumah tangga murni (tidak memiliki pekerjaan sampingan lain) dan sebanyak $45,36 \%$ adalah ibu rumah tangga profesi atau yang memiliki pekerjaan sampingan lain. Pekerjaan tersebut diantaranya adalah PNS, wiraswasta, karyawan swasta, pedagang dan buruh.

Rata-rata konsumsi daging sapi responden adalah $0,25-0,5 \mathrm{~kg} / \mathrm{RT} /$ bulan dengan frekuensi konsumsi dua kali per bulan. Sebanyak 51,55\% ibu rumah tangga membeli daging sapi di tukang sayur disebabkan alasan waktu, tenaga dan transportasi yang lebih efektif dan efisien, sedangkan sisanya $48,45 \%$ ibu rumah tangga lebih memilih membeli daging sapi secara langsung di pasar dikarenakan mereka dapat mengamati dan memilih bagian-bagian sapi sesuai keinginan.

Organisasi yang diikuti oleh responden 
adalah PKK, Keagamaan, Darma wanita, Koperasi dan Posyandu. Informasi mengenai konsep daging sapi yang ASUH pada ibu rumah tangga di Desa Baturetno masih tegolong minim. Seperti yang tertulis pada Tabel 2, sebanyak 47,42\% responden hanya mengikuti 2 organisasi sehingga keaktifan responden dalam mengikuti organisasi masyarakat masih tergolong rendah. Ibu rumah tangga hanya mengikuti organisasi masyarakat di lingkungan sekitarnya saja, seperti kegiatan PKK dan keagamaan. Apabila ada ibu rumah tangga yang tergolong banyak mengikuti keanggotaan organisasi masyarakat disebabkan oleh beberapa faktor yaitu pekerjaan, relasi dan niat atau motivasi. Organisasi yang diikuti oleh responden belum berperan besar dalam menyampaikan informasi mengenai konsep daging sapi yang ASUH, hal tersebut disebabkan oleh kurangnya peran organisasi masyarakat dalam memberi informasi mengenai bidang peternakan dan pertanian.

Kurangnya peran organisasi masyarakat dalam menyampaikan informasi mengenai konsep daging sapi yang ASUH sangat disayangkan mengingat pengetahuan ibu rumah tangga mengenai bidang peternakan

Tabel 3. Jumlah, Persentase dan Skor Pengetahuan Responden Berdasarkan Karakteristik

\begin{tabular}{|c|c|c|c|c|}
\hline Label & Indikator & Jumlah & Persentase & Skor \\
\hline & & --- (orang) --- & --- (\%) --- & \\
\hline $\mathrm{X}_{1}$ & $\leq 30$ & 5 & 5,15 & 68,60 \\
\hline \multirow{4}{*}{ Usia (tahun) } & $31-40$ & 26 & 26,80 & 70,00 \\
\hline & $41-50$ & 32 & 32,99 & 68,56 \\
\hline & $51-60$ & 29 & 29,90 & 63,20 \\
\hline & $>60$ & 5 & 5,15 & 63,00 \\
\hline $\mathrm{X}_{2}$ & Tidak lulus SD & 2 & 2,06 & 53,50 \\
\hline \multirow[t]{4}{*}{ Pendidikan } & Lulus SD & 13 & 13,40 & 57,54 \\
\hline & Lulus SMP & 21 & 21,65 & 64,43 \\
\hline & Lulus SMA & 56 & 57,73 & 69,86 \\
\hline & Lulus PT/Akademi & 5 & 5,15 & 76,00 \\
\hline$X_{3}$ & 1 & 6 & 6,19 & 60,67 \\
\hline Jumlah anggota & 2 & 32 & 32,99 & 63,88 \\
\hline \multirow[t]{3}{*}{ keluarga (orang) } & 3 & 35 & 36,08 & 68,75 \\
\hline & 4 & 19 & 19,59 & 69,42 \\
\hline & $>4$ & 5 & 5,15 & 75,00 \\
\hline $\mathrm{X}_{4}$ & $\leq 1.000 .000$ & 21 & 21,65 & 61,57 \\
\hline Pendapatan keluarga & $1.100 .000-1.500 .000$ & 31 & 31,96 & 65,52 \\
\hline \multirow[t]{3}{*}{ (Rp/bulan) } & $1.600 .000-2.000 .000$ & 35 & 36,08 & 69,83 \\
\hline & $2.100 .000-2.500 .000$ & 7 & 7,22 & 72,43 \\
\hline & $>2.500 .000$ & 3 & 3,09 & 75,00 \\
\hline $\mathrm{X}_{5}$ & 0 kali & 12 & 12.37 & 54,25 \\
\hline Kesempatan & 1 kali & 22 & 22,68 & 63,77 \\
\hline memperoleh & 2 kali & 45 & 46,39 & 69,51 \\
\hline informasi (sebulan & 3 kali & 16 & 16,49 & 73,13 \\
\hline terakhir) & $>3$ kali & 2 & 2,06 & 74,00 \\
\hline $\mathrm{X}_{6}$ & 0 & 5 & 5,15 & 61,00 \\
\hline Keanggotaan dalam & 1 & 37 & 38,14 & 61,86 \\
\hline organisasi masyarakat & 2 & 46 & 47,42 & 70,50 \\
\hline \multirow[t]{2}{*}{ (sebulan terakhir) } & 3 & 9 & 9,28 & 73,67 \\
\hline & $>3$ & 0 & 0,00 & 0,00 \\
\hline
\end{tabular}

Sumber: Data Primer Diolah (2017). 
dan pertanian sangat penting dalam pencapaian konsumsi gizi yang baik dalam keluarga.

Menurut penelitian Alfando (2013) cara mengatasi hambatan dalam mencari dan menyampaikan informasi dalam masyarakat adalah dengan mengadakan pertemuan dan evaluasi secara rutin serta membahas keberlangsungan masalah atau kendala yang dihadapi oleh kelompok, sehingga dapat ditemukan solusi atas permasalahan yang dihadapi.

Terdapat beberapa responden di Dusun Batu Kidul RT 02 RW 09 yang memelopori diadakannya tabungan daging sapi. Tabungan tersebut masuk dalam kegiatan PKK dan rutin

Tabel 4. Pertanyaan dan Sebaran Skor Responden dalam Persen tentang Konsep Daging Sapi yang ASUH

\begin{tabular}{|c|c|c|c|c|c|c|}
\hline \multirow{2}{*}{ No } & \multirow{2}{*}{ Pertanyaan } & \multicolumn{5}{|c|}{ Skor $(\%)$} \\
\hline & & 1 & 2 & 3 & 4 & 5 \\
\hline \multicolumn{7}{|c|}{ Aspek Aman } \\
\hline 1. & Penyakit menular hewan & 9,28 & 36,08 & 48,45 & 6,19 & 0,00 \\
\hline 2. & Penyimpanan tanpa pendingin & 20,62 & 0,00 & 2,06 & 13,40 & 63,92 \\
\hline 3. & $\begin{array}{l}\text { Penyimpanan dengan pendingin (non } \\
\text { freezer) }\end{array}$ & 72,16 & 13,40 & 1,03 & 0,00 & 13,40 \\
\hline 4. & $\begin{array}{l}\text { Ciri-ciri daging sapi yang aman dilihat } \\
\text { dari beberapa kriteria }\end{array}$ & 0,00 & 8,25 & 19,59 & 18,56 & 53,61 \\
\hline 5. & Bahan pengemas daging sapi & 0,00 & 0,00 & 0,00 & 18,56 & 81,44 \\
\hline \multicolumn{7}{|c|}{ Aspek Sehat } \\
\hline 6. & Kandungan gizi daging sapi & 6,19 & 16,49 & 47,42 & 25,77 & 4,12 \\
\hline 7. & $\begin{array}{l}\text { Standar konsumsi daging sapi yang } \\
\text { dianjurkan di Indonesia }\end{array}$ & 67,01 & 17,53 & 2,06 & 0,00 & 13,40 \\
\hline 8. & Ciri-ciri daging sapi sehat & 1,03 & 7,22 & 24,74 & 24,74 & 42,27 \\
\hline 9. & $\begin{array}{l}\text { Kandungan nutrisi daging sapi dengan } \\
\text { khasiat tertentu }\end{array}$ & 5,15 & 1,03 & 2,06 & 11,34 & 80,41 \\
\hline 10. & $\begin{array}{l}\text { Penyakit jika berlebihan mengkonsumsi } \\
\text { daging sapi }\end{array}$ & 0,00 & 6,19 & 22,68 & 38,24 & 32,99 \\
\hline \multicolumn{7}{|c|}{ Aspek Utuh } \\
\hline 11. & $\begin{array}{l}\text { Menjawab benar atau salah dari } \\
\text { beberapa pilihan }\end{array}$ & 5,15 & 20,62 & 46,39 & 23,71 & 4,12 \\
\hline 12. & $\begin{array}{l}\text { Alasan dianjurkan membeli daging sapi } \\
\text { yang utuh }\end{array}$ & 51,55 & 48,45 & 0,00 & 0,00 & 0,00 \\
\hline 13. & Bagian-bagian daging sapi & 0,00 & 52,58 & 44,33 & 3,09 & 0,00 \\
\hline 14. & Bagian-bagian non daging sapi & 6,19 & 36,08 & 53,61 & 4,12 & 0,00 \\
\hline 15. & Cara menjaga keutuhan daging sapi & 65,98 & 32,99 & 1,03 & 0,00 & 0,00 \\
\hline \multicolumn{7}{|c|}{ Aspek Halal } \\
\hline 16. & Syarat daging sapi dapat dikatakan halal & 6,19 & 11,34 & 56,39 & 32,99 & 3,09 \\
\hline 17. & Bahan alat menyembelih sapi & 1,03 & 7,22 & 25,77 & 39,18 & 26,80 \\
\hline 18. & Posisi sapi ketika disembelih & 1,03 & 2,06 & 1,03 & 37,11 & 58,76 \\
\hline 19. & $\begin{array}{l}\text { Bagian tubuh yang harus terpotong saat } \\
\text { hewan disembelih }\end{array}$ & 0,00 & 8,25 & 29,90 & 44,33 & 17,53 \\
\hline 20. & $\begin{array}{l}\text { Sikap untuk memastikan kehalalan } \\
\text { daging sapi }\end{array}$ & 98,97 & 0,00 & 1,03 & 0,00 & 0,00 \\
\hline
\end{tabular}

Sumber: Data Primer Diolah (2017). 
dilaksanakan satu kali tiap bulan. Latar belakang diadakannya arisan ini adalah mahalnya harga daging sapi menjelang hari raya Idul Fitri, sehingga berapapun harga yang ditentukan penjual akan tetap diterima oleh pembeli terlepas dari kondisi daging sapi tersebut. Kegiatan ini bertujuan untuk meringankan beban biaya ibu rumah tangga dalam membeli daging sapi saat menjelang hari raya Idul Fitri. Telah ada kesepakatan harga daging sapi per kilogram antara penjual dengan pembeli pada periode sebelumnya. Ibu rumah tangga yang membeli daging sapi $1 \mathrm{~kg}$ atau lebih akan menabung sejumlah Rp 30.000/bulan atau kelipatannya untuk mencicil uang mereka sehingga pada saat menjelang hari raya Idul Fitri uang tabungan yang telah dikumpulkan sudah cukup dan memenuhi untuk disetorkan kepada penjual.

\section{Gambaran Umum Pengetahuan Tentang Konsep Daging Sapi yang ASUH di Desa Baturetno}

Berdasarkan pertanyaan yang diajukan, diketahui pengetahuan responden di Desa Baturetno seperti pada Tabel 4. Berdasarkan Tabel 4 dapat diketahui bahwa untuk aspek aman, responden belum banyak mengetahui tentang macam-macam penyakit yang dapat menular dari hewan ke manusia serta belum mengetahui waktu maksimum daging sapi dapat bertahan apabila disimpan dengan pendingin.

Pada aspek sehat, responden belum mengetahui kandungn nutrisi serta standar konsumsi daging sapi yang dianjurkan di
Indonesia. Begitupula pada aspek utuh dan halal, masih banyak responden yang belum bisa menjawab pertanyaan dengan optimal.

Gambaran tingkat pengetahuan tentang konsep daging sapi yang ASUH dapat dilihat pada Tabel 5 yang menunjukkan bahwa skor tingkat pengetahuan ibu rumah tangga mengenai konsep daging sapi yang ASUH di desa Baturetno sebanyak 77,32\% berada pada range skor $47-73$, sehingga tingkat pengetahuan ibu rumah tangga mengenai konsep daging sapi yang ASUH berada pada kategori sedang atau menengah.

Martindah dan Saptati (2007) menyatakan bahwa kurangnya pengetahuan konsumen dalam memilih daging sapi yang baik dapat disebabkan oleh beberapa faktor, salah satunya adalah masih lemahnya kemampuan konsumen dalam memilih dan memperhatikan kualitas daging sapi.

Faktor lainnya dapat dipengaruhi oleh keanggotaan dalam organisasi masyarakat dan kesempatan memperoleh informasi mengenai konsep daging sapi yang ASUH. Ibu rumah tangga yang sering mendapat informasi akan meningkatkan pengetahuan dan pemahamannya terkait informasi yang diperoleh. Hal ini sesuai dengan penelitian yang dilakukan oleh Sriyono (2015) pada masyarakat di Desa Kronjo tentang kasus ikan berformalin. Masyarakat sudah banyak yang mengetahui kasus tersebut, akan tetapi sebagian besar dari mereka hanya sekedar mengetahui tetapi tidak paham dengan ciri-ciri ikan berformalin serta bagaimana pencegahannya.

Tabel 5. Jumlah dan Persentase Responden Berdasarkan Kategori Pengetahuan Tentang Konsep Daging Sapi yang ASUH

\begin{tabular}{lccr}
\hline \multicolumn{1}{c}{ Kategori } & Skor & Jumlah & Persentase \\
\hline & & $---($ orang) & $---(\%)---$ \\
Rendah & $20-46$ & 3 & 3,09 \\
Sedang & $47-73$ & 81 & 85,51 \\
Tinggi & $74-100$ & 13 & 13,40 \\
\hline
\end{tabular}

Sumber: Data Primer Diolah (2017). 
Faktor-Faktor Yang Mempengaruhi Tingkat Pengetahuan Ibu Rumah Tangga di Desa Baturetno

Faktor-faktor yang mempengaruhi pengetahuan tingkat pengetahuan ibu rumah tangga tentang konsep daging sapi yang ASUH menggunakan variabel usia, pendidikan, jumlah anggota keluarga, pendapatan keluarga, kesempatan memperoleh informasi dan keanggotaan dalam organisasi masyarakat. Berdasarkan hasil uji normalitas dengan menggunakan model Kolmogorov-Smirnov data berdistribusi normal.

Hasil uji autokorelasi, multikolineritas dan heterokedastisitas dapat diketahui bahwa asumsi klasik yang disyaratkan untuk analisis data dengan analisis regresi linier berganda sudah terpenuhi. Hasil analisis data dengan analisis regresi linier berganda dan pengujian hipotesis dengan menggunakan uji $F$ dan uji $t$ tertera pada Tabel 6.

Hasil penelitian menunjukkan nilai koefisien regresi untuk masing-masing variabel pada Tabel 6. Persamaan regresi sebagai berikut:

$\mathrm{Y}=41,184-0,144 \mathrm{X}_{1}+1,352 \mathrm{X}_{2}+1,690$

$X_{3}+0,987 X_{4}+3,632 X_{5}+1,723 X_{6}$
Pengaruh faktor usia, pendidikan, jumlah anggota keluarga, pendapatan keluarga, kesempatan memperoleh informasi dan keanggotaan dalam organisasi masyarakat terhadap pengetahuan responden mengenai daging sapi yang ASUH dapat diketahui melalui nilai adjusted $R$ square, uji $\mathrm{F}$ dan uji $\mathrm{t}$ pada Tabel 4 yang dapat dijelaskan sebagai berikut:

a. Berdasarkan analisis diperoleh nilai adjusted $\mathrm{R}$ square sebesar 0,762 artinya $76,2 \%$ menjelaskan variabel bebas terhadap pengetahuan responden tentang daging sapi yang ASUH, sedangkan $23,8 \%$ dijelaskan oleh faktor lain yang tidak dimasukkan dalam model regresi.

b. Berdasarkan analisis uji $\mathrm{F}$ diperoleh nilai signifikansi sebesar 0,000. Nilai signifikansi menunjukkan nilai $\leq 0,05$, artinya variabel usia, pendidikan, jumlah anggota keluarga, pendapatan keluarga, kesempatan memperoleh informasi dan keanggotaan dalam organisasi masyarakat berpengaruh signifikan terhadap pengetahuan responden di Desa Baturetno tentang daging sapi yang ASUH.

c. Berdasarkan analisis uji $\mathrm{t}$ diperoleh hasil bahwa variabel pendidikan, jumlah anggota keluarga, pendapatan keluarga,

Tabel 6. Hasil Analisis Regresi Linier Berganda

\begin{tabular}{|c|c|c|c|}
\hline Variabel & $\begin{array}{l}\text { Koefisien } \\
\text { Regresi }\end{array}$ & t Hitung & Sig \\
\hline Konstanta (a) & 41,184 & 14,886 & $0,000 * *$ \\
\hline Usia (X1) & $-0,144$ & $-0,335$ & 0,738 \\
\hline Pendidikan (X2) & 1,352 & 2,105 & $0,038^{*}$ \\
\hline Jumlah anggota keluarga (X3) & 1,690 & 4,112 & $0,000 * *$ \\
\hline Pendapatan keluarga (X4) & 0,987 & 2,222 & $0,029 *$ \\
\hline Kesempatan memperoleh informasi (X5 & 3,632 & 6,806 & $0,000 * *$ \\
\hline Keanggotaan dalam organisasi masyarakat (X6) & 1,723 & 2,572 & $0,012 * *$ \\
\hline Adjusted R Square & & & 0,762 \\
\hline $\mathrm{F}$ & 47,985 & & $0,000 * *$ \\
\hline
\end{tabular}

Sumber: Data Primer Diolah (2017).

Keterangan: *Nyata pada tingkat kepercayaan 95\% $(\alpha=0,05 \%)$

**Nyata pada tingkat kepercayaan $99 \%(\alpha=0,01 \%)$ 
kesempatan memperoleh informasi dan keanggotaan dalam organisasi masyarakat berpengaruh signifikan, sedangkan variabel usia tidak berpengaruh signifikan terhadap pengetahuan responden mengenai daging sapi yang ASUH.

Hasil uji t menunjukkan bahwa variabel pendidikan memberikan pengaruh nyata terhadap pengetahuan ibu rumah tangga. Hal ini menunjukkan bahwa semakin tinggi tingkat pendidikan ibu rumah tangga maka akan meningkatkan kesadaran mengenai cara memilih bahan pangan baik untuk dikonsumsi keluarganya. Selain itu keinginan ibu rumah tangga dalam mencari informasi semakin tinggi sehingga informasi lebih cepat diterima. Fatmawati (1995) menyatakan bahwa pendidikan yang tinggi akan meningkatkan kesadaran seorang ibu rumah tangga untuk mencari informasi sebanyakbanyaknya dalam usaha menyejahterakan keluarganya, termasuk informasi tentang kualitas pangan dan pengetahuan gizi. Pernyataan diatas juga didukung oleh pendapat Ariningsih (2008) yang menyatakan bahwa pendidikan berkorelasi erat dengan pendapatan dan pengetahuan tentang pangan dan gizi. Semakin tinggi tingkat pendidikan maka pengetahuan mengenai produk pangan akan meningkat.

Jumlah anggota keluarga memberikan pengaruh nyata terhadap pengetahuan ibu rumah tangga, artinya semakin banyak jumlah anggota keluarga maka ibu akan mencari informasi mengenai cara untuk mendapatkan kualitas pangan yang baik sehingga tingkat pengetahuan akan semakin tinggi. Hal ini didukung oleh penelitian yang dilakukan Damayanti (2017) yang menyatakan bahwa jumlah anggota keluarga berpengaruh secara signifikan terhadap tingkat pengetahuan ibu mengenai baik buruknya gizi dari pangan yang dikonsumsi. Hal ini disebabkan oleh semakin besar jumlah anggota keluarga maka semakin memungkinkan bagi para ibu untuk meningkatkan pengetahuannya baik itu dari media elektronik, media cetak maupun sosialisasi.

Pendapatan keluarga memberikan pengaruh nyata terhadap pengetahuan ibu rumah tangga. Hal tersebut menandakan bahwa pendapatan yang tinggi akan berpengaruh dalam menunjang kebutuhan untuk mengakses informasi sehingga pengetahuan masyarakat meningkat. Ariani dan Rachman (2008) menyatakan bahwa melalui pendapatan maka rumah tangga memiliki kemampuan untuk memperoleh kebutuhan yang diinginkan. Penelitian yang dilakukan oleh Aryanti (2010) menyatakan bahwa pendapatan keluarga merupakan salah satu faktor risiko yang mempengaruhi status gizi balita di wilayah kerja Puskesmas Sidoharjo. Pendapatan yang baik akan menyebabkan seseorang mencari informasi mengenai kualitas pangan yang baik untuk dikonsumsi keluarga. Semakin banyak banyak pengetahuan tersebut, maka ia akan semakin memperhitungkan jenis dan jumlah makanan yang diperolehnya untuk dikonsumsi.

Kesempatan memperoleh informasi memberikan pengaruh positif terhadap pengetahuan ibu rumah tangga. Informasi mengenai konsep daging sapi yang ASUH diperoleh dari tayangan berita di televisi, radio, surat kabar dan organisasi. Ibu rumah tangga yang lebih sering mendapatkan informasi dari berbagai sumber akan menambah tingkat pengetahuannya. Hal ini sesuai dengan pendapat Notoatmodjo (2003) dan Gayatri dan Vaarst (2016) yang menjelaskan bahwa seseorang yang mempunyai peluang informasi lebih banyak akan berdampak pada tingkat pengetahuan yang lebih jelas. Sumarwan (2011) juga 
menyatakan bahwa semakin banyak informasi yang diakses maka semakin banyak referensi yang dapat menjadi pertimbangan individu dalam mengambil keputusan.

Keanggotaan dalam organisasi masyarakat memberikan pengaruh positif terhadap pengetahuan ibu rumah tangga. Hasil tersebut menandakan semakin sering responden tergabung dalam organisasi maka responden semakin mendapat kesempatan dalam meningkatkan pengetahuan (Gayatri and Vaarst, 2015). Namun dalam kondisi lapangan yang sebenarnya, organisasi yang diikuti oleh ibu rumah tangga di Desa Baturetno sangat jarang memberikan informasi mengenai bidang peternakan dan pertanian. Ibu rumah tangga yang mengikuti lebih dari 3 organisasi adalah ibu rumah tangga profesi, seperti Pegawai Negeri Sipil (PNS). Hal tersebut menyebabkan luasnya jaringan komunikasi ibu rumah tangga sehingga memungkinkan jika ia mengikuti berbagai organisasi dan memiliki tingkat informasi yang tinggi. Gerungan (2004) menyatakan bahwa organisasi memberikan fasilitas dan kesempatan bagi individu untuk berkembang, menyalurkan pendapat dan saling berbagi informasi dari satu pihak ke pihak lain sehingga organisasi mempunyai peranan penting dalam proses perubahan pola piker anggotanya.

Faktor usia tidak berpengaruh nyata terhadap pengetahuan. Kondisi responden di lapangan menunjukkan bahwa bertambahnya usia tidak berbanding lurus dengan pengetahuan ibu rumah tangga mengenai daging sapi yang aman, sehat, utuh dan halal. Analisis data menunjukkan bahwa skor pengetahuan responden yang berusia lebih muda lebih tinggi dibandingkan responden yang berusia lanjut. Ahmadi (2004) menyatakan bahwa usia merupakan salah satu faktor yang mempengaruhi kapasitas daya ingat. Daya ingat manusia dipengaruhi oleh faktor individu seperti sifat, keadaan jasmani, keadaan rohani dan usia. Pada usia lanjut, daya ingat merupakan salah satu fungsi kognitif yang sering kali mengalami penurunan.

Informasi yang didapatkan responden mengenai daging sapi yang ASIH berasal dari beberapa sumber, yaitu televisi, radio, internet, koran, majalah dan organisasi yang diikuti. Media informasi yang paling berperan adalah televisi, koran dan majalah. Minat dan keingintahuan responden dalam mencari informasi mengenai daging sapi yang aman, sehat, utuh dan halal belum tergolong tinggi. Hal tersebut disebabkan oleh kondisi responden yang belum secara mandiri mengakses informasi tersebut melalui media massa. Penelitian yang dilakukan oleh Dalyono (2010) memberikan hasil bahwa media massa dapat memberi pengaruh yang signifikan terhadap pembentukan sikap dan perilaku manusia. Media massa juga mempengaruhi pemanfaatan teknologi informasi dalam kehidupan sehari-hari. Hardinsyah (2007) juga menyatakan bahwa wanita lebih sering mendapatkan informasi dari media cetak, khususnya majalah dan koran.

Peran organisasi masyarakat dalam memberikan informasi mengenai bidang peternakan dan pertanian, khususnya konsep daging sapi yang aman, sehat, utuh dan halal pun masih kurang sehingga berdampak pada pengetahuan yang terbatas. Informasi yang sering diberikan adalah tentang kesehatan dan lingkungan dikarenakan hal tersebut lebih relevan dan sering ditemukan permasalahan dalam kehidupan sehari-hari.

\section{SIMPULAN DAN SARAN}

Tingkat pengetahuan responden di Desa Baturetno mengenai konsep daging sapi yang 
aman, sehat, utuh, halal (ASUH) termasuk dalam kategori sedang. Pengetahuan ibu rumah tangga tentang konsep daging sapi yang ASUH dipengaruhi oleh faktor eksternal berupa kesempatan memperoleh informasi dan keanggotaan dalam organisasi masyarakat, serta faktor internal yang terdiri dari usia, pendidikan, jumlah anggota keluarga, dan pendapatan keluarga. Variabel yang berpengaruh signifikan adalah pendidikan, jumlah anggota keluarga, pendapatan keluarga, kesempatan memperoleh informasi dan keanggotaan dalam organisasi masyarakat berpengaruh signifikan, sedangkan variabel usia tidak berpengaruh signifikan terhadap pengetahuan responden mengenai daging sapi yang ASUH.

\section{DAFTAR PUSTAKA}

Ahmadi, A. 2004. Sosiologi Pendidikan. Rineka Cipta, Jakarta.

Alfando, J.W.S. 2013. Peranan kelompok informasi masyarakat (KIM) dalam mewujudkan desa mandiri di Desa Sidomulyo Kecamatan Anggana, Kutai Kartanegara. J. Ilmu Komunikasi 1 (2) : $109-125$.

Ariani, M. dan H.P.S Rachman. 2008. Keberhasilan Diversifikasi Pangan Tanggung Jawab Bersama. Badak Pos, Banten. hal. 2.

Ariningsih, E. 2008. Pengaruh faktor-faktor sosial ekonomi terhadap konsumsi susu dan produk olahan susu. Semiloka Nasional Prospek Industri Sapi Perah Menuju Perdagangan Bebas. Pusat Analisis Sosial Ekonomi dan Kebijakan, Bogor. 2008. p. 469 - 475.

Aryanti, M.A. 2010. Hubungan antara pendapatan keluarga, pengetahuan gizi ibu, dan pola makan dengan status gizi balita di wilayah kerja Puskesmas Sidoharjo Kabupaten Sragen. Skripsi. Program Sarjana Universitas Negeri Semarang.
Badan Pusat Statistik Kabupaten Wonogiri. 2015. Kecamatan Baturetno dalam Angka Tahun 2015. Badan Pusat Statistik, Wonogiri.

Dalyono, C.T. 2010. Pengaruh media massa dan pengetahuan tentang teknologi informasi terhadap pemanfaatan teknologi informasi dan tingkat modernitas generasi muda Kota Yogyakarta. J. Ilmu Komunikasi 8 (1) : $86-95$.

Damayanti, Rina. 2017. Pengaruh pengetahuan ibu tentang gizi dan pola pemberian makan terhadap kejadian gizi kurang pada balita di wilayah kerja Puskesmas Gajahan Surakarta. Skripsi. Program Sarjana Universitas Muhammadiyah Surakarta.

Direktorat Kesmavet. 2003. Kiat memilih daging yang aman dan sehat. Direktorat Kesmavet. Direktorat Jenderal Bina Produksi Peternakan, Departemen Pertanian. Jakarta.

Fatmawati, E. 1995. Beberapa Faktor yang Mempengaruhi Alokasi Pengeluaran dan Tingkat Konsumsi Pangan Keluarga (Studi Kasus di Kelurahan Tanah Sareal, Bogor). Fakultas Pertanian Institut Pertanian Bogor, Bogor. [Skripsi].

Gayatri, S. and Vaarst, M. 2015. The Implementation of Indonesia's Beef Self Sufficiency Programme (BSSP) as Seen from a Farmer-Family Perspective. Journal of Rural and Community Development 10, 2(2015) 166-186.

Gayatri, S. and Vaarst, M. 2016. Bridging Expectations: Extension Agents' Perception of a Gap between Expectations and Experience when Implementing the Indonesian Beef SelfSufficiency Programme. Int. J. Agric. Ext. Vol 4, No 1 (2016).

Gerungan, W.A. 2004. Psikologi Sosial. PT Refika Aditama, Bandung.

Hamdi A.S. 2014. Metode Penelitian Kuantitatif Aplikasi dalam Pendidikan. 
Deepublish, Yogyakarta.

Hardinsyah, H.A.M. 2007. Inovasi Gizi dan Pengembangan Modal Sosial Bagi Peningkatan Kualitas Hidup Manusia Dan Pengentasan Kemiskinan. IPB Press, Bogor.

Martindah, E dan Saptati, RA. 2007. Kesehatan dan keamanan produk pangan hewani. Seminar Nasional Hari Pangan Sedunia XXVII. Bogor, 21 Nopember 2007. p. 94-100.

Notoatmodjo, S. 2003. Pengembangan Sumber Daya Manusia. PT Rineka Cipta, Jakarta.

Republika, 2014. Daging Sapi Dicampur Babi Dijual di Pasar. http://www.republika.co.id/berita/nasion al/daerah/14/09/18/nc33b6-daging-sapidicampur-babi-dijual-di-pasar (diakses 3 Oktober 2016).

Setiabudi, M.U., W.B. Parera dan R.A. FarFar. 2013. Proses pengambilan keputusan konsumen dalam pembelian sayuran segar studi kasus Hypermart Ambon City Center Kota Ambon. J.
Agribisnis Kepulauan. 1 (4) : 25-40.

Sriyono. 2015. Pengaruh tingkat pendidikan dan pemahaman masyarakat tentang ikan berformalin terhadap kesehatan masyarakat. J. Factor Exacta. 8 (1) : 7991.

Sulaiman, W. 2004. Analisis Regresi Menggunakan SPSS. Contoh Kasus dan Pemecahannya. Penerbit Andi, Yogyakarta.

Sumarwan, U. 2011. Perilaku Konsumen : Teori dan Penerapannya dalam Pemasaran. Ghalia Indonesia, Bogor.

Suryana, A. 2007. Dukungan teknologi penyediaan produk pangan peternakan bermutu, aman dan halal. Seminar Nasional Hari Pangan Sedunia XXVII. Bogor, 21 Nopember 2007. p. 32-40.

Wirartha I.M. 2006. Metode Penelitian Sosial Ekonomi. Penerbit Andi, Yogyakarta.

Zulfanita. H.D. Arifin dan Priyono. 2013. Keamanan dan pengamanan pangan produk daging sapi bermutu dan halal di Indonesia. J. Surya Agritama. 2 (1): 6375. 